\title{
EKG or ECG Device Subassembly Device
}

National Cancer Institute

\section{Source}

National Cancer Institute. EKG or ECG Device Subassembly Device. NCI Thesaurus. Code C49935.

An electronic device designed to record the electric currents of a beating heart, as part of a larger device. 